\title{
An approach towards COVID-19 pandemic with Yoga and Naturopathy interventions- Tamilnadu model
}

\author{
T. Prabu a , K. Kahlil Subramanian ${ }^{\text {b }}$, N. Manavalan ${ }^{\text {c }}$, S.T. Venkateswaran ${ }^{\text {d }}$, K. Maheshkumar ${ }^{\text {e, }}$ \\ ${ }^{a}$ Department of Philosophy of Nature Cure, Govt. Yoga \& Naturopathy Medical College \& Hospital, Chennai, Tamilnadu, India \\ ${ }^{\mathrm{b}}$ Department of Research, Govt. Yoga \& Naturopathy Medical College \& Hospital, Chennai, Tamilnadu, India \\ ${ }^{\mathrm{c}}$ Department of Naturopathy, Govt. Yoga \& Naturopathy Medical College \& Hospital, Chennai, Tamilnadu, India \\ d Department of Yoga, Govt. Yoga \& Naturopathy Medical College \& Hospital, Chennai, Tamilnadu, India \\ e Department of Physiology and Biochemistry, Govt. Yoga \& Naturopathy Medical College \& Hospital, Chennai, Tamilnadu, India
}

A R T I C L E I N F O

\section{Keywords}

Covid 19

Mental health

Yoga and naturopathy

On March 24, 2020, India announced nationwide lockdown in an effort to manage the Coronavirus disease 2019 (Covid-19) pandemic. Till date more than 12 million people got infected by Covid-19 and more than 0.162 million deaths reported. ${ }^{1}$ Government of India (GoI), has efficiently managed this pandemic along with the direction of World Health Organization (WHO) and Indian council of Medical research (ICMR) recommendations. ${ }^{2}$ In addition, Ministry of AYUSH (MoA) also came out with various adjuvant remedies for the control of Covid-19 pandemic. ${ }^{3}$ In this regard, Tamilnadu government in association with Indian System of Medicine (ISM) initiated effective control measures for prevention of infection and enhancement of immune system to combat the Covid-19. Yoga and Naturopathy, an Indian System of Medicine that focuses on treating the root cause of disease, proposed an advisory (Table 1) on implementing Yoga \& Naturopathy interventions for Covid-19 patients together with allopathic management. This advisory includes yoga (asana, pranayama, meditation \& kriya), hydrotherapy (hot water drinking, hot water gargling and steam inhalation), aromatherapy (eucalyptus oil and peppermint oil), self-acupressure and sun bath. In addition to that, natural immune booster which includes peeled crushed Ginger, Tulsi (Basil) leaves, pepper powder and crushed adhimaduram also provided for improving their natural immunity. These immune boosting hot drinks were prepared under expert's supervision and delivered to the patients undergoing treatment for Covid-19 along with conventional care. The focus of the interventions was on improving the physical and mental health along with their immunity. These commonly used nutraceuticals; Ginger (Zingiber ofcinale), Tulsi (Ocimum sanctum L./Basil), pepper powder (Piper nigrum) and Ashwagandha (Withania somnifera L.) act as an anti-inflammatory, immuno-modulator and angiotensin-converting-enzyme (ACE-2) inhibitor. ${ }^{4}$ The major cause of death in Covid-19 is due to weak immune mechanisms coupled with the cytokine surge,${ }^{5}$ so these nutraceuticals were incorporated in daily routine diet as a supportive treatment against Covid-19 for reduction in the severity and mortality of the patients. Till date, more than 5,00,000 patients have been covered across 178 Covid care centers of Tamilnadu. A team of Yoga and naturopathy doctors provided the yoga and naturopathy interventions to the patients admitted in their respective Covid care centers across 37 districts of the entire state of Tamilnadu. The same interventions were shared to the patients as an E module (videos) as well, for better learning and self-practice. Specifically, two districts namely Chennai and Coimbatore which had highest positive cases (more than 15,000 patients) were effectively treated with Yoga and Naturopathy interventions (Fig. 1). Patients with asymptomatic, mild and moderate severity also received the interventions by the experienced Yoga and naturopathy doctors. One of our recent study add that there was significant reduction of anxiety and depression level as well among the Covid-19 patients by the yoga and naturopathy advisory recommended interventions. ${ }^{6}$ In addition, many patients have given positive feedback about the interventions and how it was helping them during their treatment period. After discharge, through telephonic mode most of the patients were followed up and advised to take our interventions in a regular manner for the long term benefit. Tamilnadu is the only state where the yoga and naturopathy module in Covid care management

\footnotetext{
* Corresponding author.

E-mail address: doctor.mahesh1985@gmail.com (K. Maheshkumar).
} 
Table 1

Advisory on Yoga \& Naturopathy interventions for COVID-19.

\begin{tabular}{|c|c|}
\hline Treatment & Details \\
\hline \multicolumn{2}{|l|}{ Essential care for all } \\
\hline $\begin{array}{l}\text { Natural immune boosting fresh } \\
\text { juice }\end{array}$ & $\begin{array}{l}\text { Indian Gooseberry juice }-50 \mathrm{ml} \text {, Basil Juice }-50 \mathrm{ml} \text {, Ginger Juice }-10 \mathrm{ml} \text {, Fresh Lime juice }-5 \mathrm{ml} \text {, Turmeric powder }-1 / 4 \mathrm{tsp} \text {, Water }-150 \mathrm{ml} \\
\text { Dosage: twice daily }\end{array}$ \\
\hline $\begin{array}{l}\text { Natural immune boosting hot } \\
\text { drink }\end{array}$ & $\begin{array}{l}\text { Peeled Crushed Ginger } 5 \mathrm{gm} \text {, Tulsi (Basil) leaves } 10 \mathrm{gms} \text {, Pepper powder 1/4tsp, Crushed Adhimaduram } 5 \text { gms (liquorice root), Turmeric powder } 1 / 4 \\
\text { tsp and drinking water } 250 \mathrm{ml} \text {. Boiled and given twice a day. }\end{array}$ \\
\hline Yoga therapy & $\begin{array}{l}\text { Posture (Vajrasana, Bhastrika, Bhramari), Quick relaxation technique, Deep relaxation technique, Jala Neti. } \\
\text { Twice or thrice as recommended by the physician }\end{array}$ \\
\hline \multicolumn{2}{|c|}{ Specific care for the needed patients recommended by Yoga and Naturopathy doctors } \\
\hline Warm salt water gargling & Taking $30-50 \mathrm{ml}$ of water and whirl it around the pharynx \& oral cavity \\
\hline Steam inhalation & Inhalation of steam with or without essential oils/Nochi/Neem leaves \\
\hline Sunbath & Sun exposure (20 minutes) in the morning and evening \\
\hline Aromatherapy & Eucalyptus/Peppermint/thyme/lavendar/Ajjwain oil: 1-2 drops in tissue paper or mix with gingelly oil/Coconut oil \& inhaled now and then \\
\hline
\end{tabular}

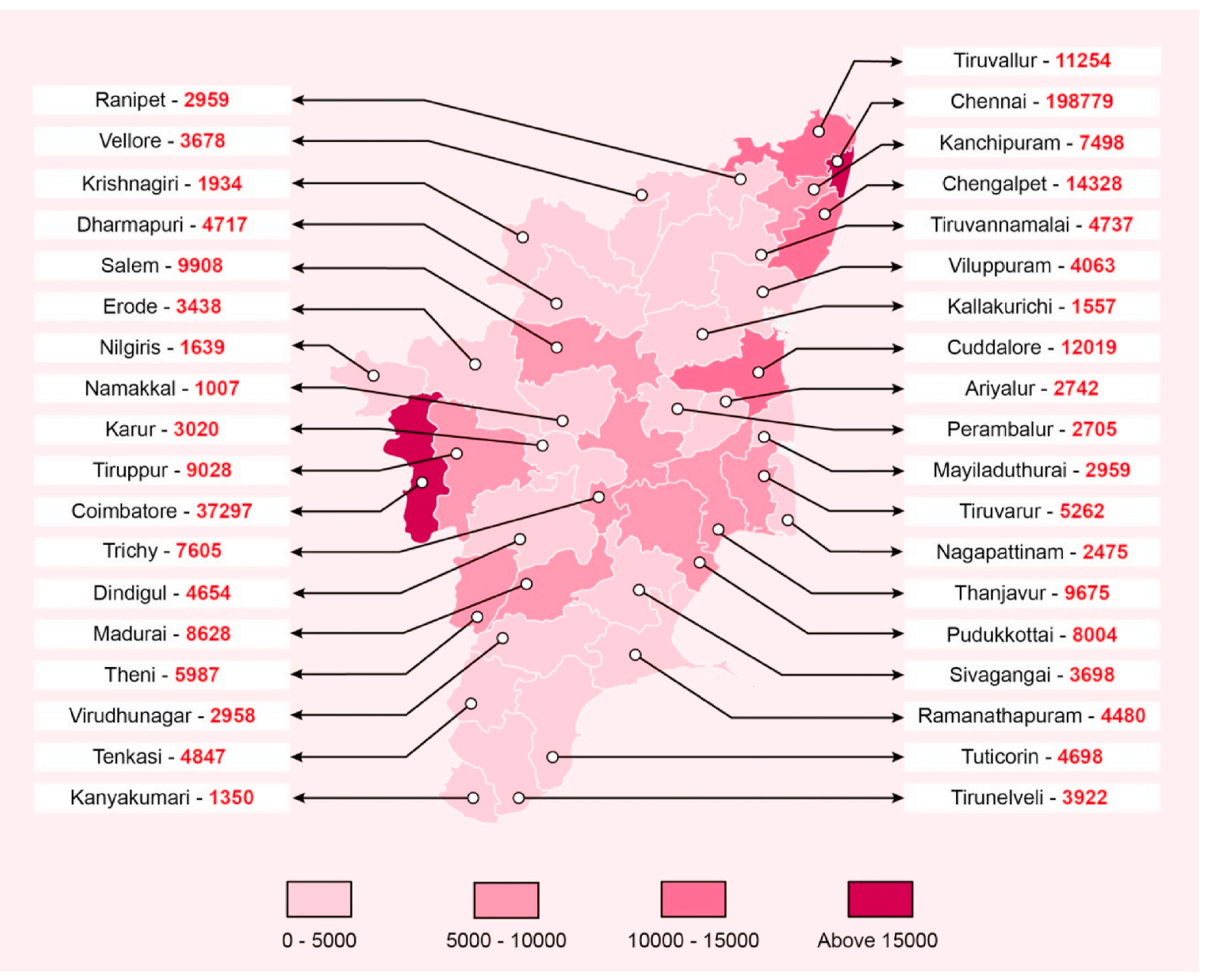

Fig. 1. District wise COVID-19 patients received Yoga and Naturopathy interventions.

designed, approved and implemented in all the districts efficiently in various modes. Successful implementation of this model is due to active Yoga and Naturopathy wing in all the districts headquarter government hospitals and allopathy medical college hospitals across the state. This kind of model can be extended national wide for better care and management of Covid-19 pandemic.

\section{Author agreement}

Category 1.

Conception and design of study: N.Manavalan, ST Venkateswaran, Acquisition of data: T.Prabu, K.Kahlil Subramanian Analysis and/or interpretation of data: K.Maheshkumar.

Category 2.

Drafting the manuscript: T.Prabu, K.Kahlil Subramanian, K. Maheshkumar 
Revising the manuscript critically for important intellectual content: T.Prabu, K.Kahlil Subramanian, N.Manavalan, ST Venkateswaran, K. Maheshkumar

Category 3.

Approval of the version of the manuscript to be published (the names of all authors must be listed): T.Prabu, K.Kahlil Subramanian, ST Venkateswaran, N.Manavalan, K.Maheshkumar.

\section{Declaration of competing interest}

Authors declare having no conflict of interest regarding this study.

\section{Acknowledgments}

Nil.

\section{References}

1 COVID-19 update, COVID-19 IndiaMinistry of health and family Welfare. MoHFW Available online at https://www.mohfw.gov.in. Accessed April 14, 2021, 08:00 IST (GMT+5:30).

2 Clinical Management Protocol: COVID-19. Ministry of health \& family Welfare, government of India directorate general of health services (EMR division), Available online at: https://www.mohfw.gov.in/pdf/ClinicalManagementProtocolforCOVID19. pdf. Accessed April 13, 2021.

3 Ministry of AYUSH. Government of India Advisory from Ministry of AYUSH for Meeting the Challenge Arising Out of Spread of Corona Virus (Covid-19) in India. New Delhi, India: Ministry of AYUSH, Government of India; 2020, 6th Mar 2021 https://www.ayush. gov.in/docs/125.pdf.

4 Patel B, Sharma S, Nair N, Majeed J, Goyal RK, Dhobi M. Therapeutic opportunities of edible antiviral plants for COVID-19. Mol Cell Biochem. 2021 Feb 15:1-20.

5 Loganathan S, Kuppusamy M, Wankhar W, et al. Angiotensin-converting enzyme 2 (ACE2): COVID 19 gate way to multiple organ failure syndromes. Respir Physiol Neurobiol. 2021 Jan;283:103548.

6 Jenefer Jerrin R, Theebika S, Panneerselvam P, Venkateswaran ST, Manavalan N, Maheshkumar K. Yoga and Naturopathy intervention for reducing Anxiety and Depression of Covid-19 patients - a pilot study. Clinical Epidemiology and Global Health. 2021;11:100800. https://doi.org/10.1016/j.cegh.2021.100800. 